AnNa GolejewsKa

Uniwersytet Gdański

\title{
Innowacyjność a konkurencyjność regionalna krajów Grupy Wyszehradzkiej w latach 1999-2008 ${ }^{1}$
}

Niniejszy artykuł koncentruje się na ekonomicznej analizie regionów: 35. jednostek typu NUTS-2 w czterech nowych krajach członkowskich UE. Poza Polską badaniem objęte zostały regiony Węgier, Czech i Słowacji. Pierwsza część analizy zawiera przegląd koncepcji teoretycznych konkurencyjności regionalnej. W kolejnej części zaprezentowano potencjalny wpływ innowacji na konkurencyjność regionalną. Ostatnia część opracowania zawiera analizę empiryczną innowacyjności regionów Grupy Wyszehradzkiej w latach 1999-2008 i związku z poziomem ich konkurencyjności. Badanie przeprowadzone zostało w oparciu o dane pochodzące z bazy danych Eurostat (Regional Statistics) i OECD (OECD Regional Database). Z uwagi na dostępność danych na poziomie regionalnym, badaniem objęto dwa obszary innowacyjności, tj. tworzenie wiedzy i zasoby ludzkie. Za miernik konkurencyjności przyjęto poziom i dynamikę PKB per capita.

\section{KONKURENCYJNOŚĆ REGIONALNA: ASPEKT TEORETYCZNY}

W ostatnich latach, głównie w wyniku wzrostu zainteresowania tematyką regionalną, zjawisko konkurencyjności regionalnej zyskuje na znaczeniu nie tylko jako przedmiot analiz ekonomicznych, ale również jako istotny element rozważań polityk. Znajduje to swój wyraz w próbie zdefiniowania i oceny konkurencyjności regionów UE zainicjowanej przez Komisję Europejską i ściśle powiązanej z realizacją Strategii Lizbońskiej. Przytaczając definicję zawartą w Sixth Periodic Report on Social and Economic Situation of Regions in the $E U$ konkurencyjność regionalna definiowana jest jako „zdolność do produkcji dóbr i usług, które znajdują nabywców na rynku międzynarodowym przy jednoczesnym wysokim i stabilnym poziomie dochodów albo inaczej zdolność do generowania relatywnie wysokich dochodów i wysokiego poziomu zatrudnienia w warunkach trwałego poddawania się konkurencji

${ }^{1}$ Artykuł powstał częściowo w ramach projektu zrealizowanego w programie „Badania letnie” w oparciu o grant Centrum Europejskiego Natolin (2011) oraz projektu finansowanego przez Ministerstwo Nauki i Szkolnictwa Wyższego (nr 2898/B/H03/2010/39) pt. „Analiza porównawcza zmian konkurencyjności nowych krajów członkowskich w procesie integracji z Unią Europejską (na przykładzie Polski, Węgier, Czech i Słowacji)". 
międzynarodowej” i dodatkowo ,jako zdolność regionu do zapewnienia zarówno dużej ilości jak i wysokiej jakości miejsc pracy" (Sixth Periodic Report on Social and Economic Situation of Regions in the EU, 1999).

Generalnie w podejściu do pojęcia konkurencyjności regionalnej można zaobserwować dwa kierunki. W pierwszym z nich konkurencyjność regionalna rozpatrywana jest jako suma konkurencyjności firm zlokalizowanych w regionie, w drugim jako wtórna (makroekonomiczna) konkurencyjność. W przypadku konkurencyjności regionalnej rozpatrywanej przez pryzmat firm przyjmuje się założenie, że interesy firm i regionu w którym są zlokalizowane są zawsze zbieżne. Takie założenie może jednak zostać podważone, ponieważ firmy dążą do osiągnięcia jak najwyższej produktywności i zysków, podczas gdy konkurencyjność regionalna oznacza zapewnienie wysokiego poziomu zatrudnienia. Według podejścia zaproponowanego przez Komisję Europejską „,definicja konkurencyjności regionalnej powinna uwzględniać założenie, że pomimo faktu zlokalizowania w każdym regionie zarówno konkurencyjnych jak i niekonkurencyjnych firm, wspólne cechy regionu wpływają na konkurencyjność wszystkich zlokalizowanych w nim przedsiębiorstw”. Ponadto, mimo iż rola produktywności pozostaje bezsporna, a czynniki mające wpływ na jej wzrost powinny stanowić istotny element strategii rozwoju regionów, skupienie uwagi na produktywności nie powinno przesłaniać kwestii przekładania się jej wzrostu na wyższe płace i zyski.

Alternatywna definicja konkurencyjności regionalnej uwzględnia wcześniej przedstawione założenia. Zgodnie z nią konkurencyjność regionalna oznacza „zdolność gospodarki regionalnej do optymalnego wykorzystania czynników endogenicznych celem sprostania konkurencji i rozwoju na rynku krajowym i globalnym oraz adaptacji do zmian na tych rynkach”. Podobne ograniczenia występują w podejściu do konkurencyjności regionalnej jako konkurencyjności makroekonomicznej (wtórnej). Przykładem mogą być niektóre z praw rządzących handlem międzynarodowym, które nie występują bądź nie działają właściwie na poziomie regionalnym. Należą do nich m.in. zmiany kursu walutowego czy elastyczność cenowo-płacowa. Z kolei takie zjawisko, jak międzyregionalna migracja pracy i kapitału może stanowić realne zagrożenie dla regionów, inaczej niż ma to miejsce w przypadku kraju. W obliczu braku makroekonomicznych mechanizmów dostosowawczych na rynku regionalnym, koncepcja konkurencyjności makroekonomicznej nie znajduje pełnego zastosowania na poziomie regionalnym (A Study of the Factors of Regional Competitiveness. A Draft Final Report for the European Commission, s. 2-4). Konkurencyjność regionalna nie może być definiowana stricte jako konkurencyjność mikro- lub makroekonomiczna. Regionu nie można bowiem traktować ani jako czystej agregacji zlokalizowanych w nim przedsiębiorstw, ani jako „zeskalowanej” wersji kraju. Na poziomie regionalnym pojawiają się nowe wzorce konkurencji, czego przykładem są klastry, a poziom wiedzy i technologii charakteryzuje się dużym zróżnicowaniem regionalnym. Ciekawe i szerokie ujęcie konkurencyjności regionalnej zostało zaproponowane przez Meyera-Stamer’a (2008, s. 3): „Konkurencyjność terytorium oznacza zdolność poziomu lokalnego lub regionalnego do generowania wysokich i rosnących dochodów oraz wzrost środków utrzymania jego mieszkańców".

Definicja podkreśla silny związek między konkurencyjnością a dobrobytem i definiuje region konkurencyjny nie tylko przez pryzmat czynników związanych z produkcją, ale również $w$ odniesieniu do całościowej sytuacji gospodarczej i istotnego jej elementu tj. trwałego i rosnącego poziomu dobrobytu. Przytoczoną definicję zastosowano w niniejszym opracowaniu. 


\section{PotenCJALNY WPŁYW INNOWACJI NA KONKURENCYJNOŚĆ REGIONALNA}

Innowacyjność uznawana jest obecnie za główny czynnik wzrostu gospodarczego. W gospodarce opartej na wiedzy dostęp do surowców naturalnych nie gwarantuje sukcesu gospodarczego. Przykładem są tu kraje arabskie, które pomimo dysponowania największymi zasobami ropy naftowej na świecie, nie należą do najbardziej dynamicznych gospodarek.

Zrozumienie wpływu innowacji na poziom konkurencyjności regionalnej wymaga przeglądu koncepcji teoretycznych. Zgodnie z teorią przedsiębiorstwa autorstwa Schumpetera (1911), w obliczu konkurencji i spadających zysków firmy zmuszane są do wprowadzania technicznych i finansowych innowacji, a efektem ich działań jest (nieregularny) wzrost gospodarczy. W wyniku procesu „kreatywnej destrukcji”, fale innowacji uderzają w poszczególne branże w różnym czasie, prowadząc do międzygałęziowego zróżnicowania dochodów przedsiębiorstw. Według autora, innowacje w przedsiębiorstwach stanowią bazę dla długookresowego wzrostu gospodarczego. Grossmann i Helpman (1994), przyjmując założenia teorii Schumpetera dowodzą, że firmy wykazują skłonność do prowadzenia działalności innowacyjnej, ponieważ oczekują, że nowe technologie pozwolą im na czerpanie zysków z pozycji monopolistycznej przynajmniej do czasu, kiedy nowa technologia stanie się wiedzą publiczną. Definiując innowację jako proces, którego efektem jest wprowadzenie na rynek produktów wyższej jakości w porównaniu z podobnymi, obecnie dostępnymi, autorzy używają pojęcia „drabiny jakości”. Poprawa jakości oferowanych towarów i proces imitacji pozwalają krajom słabiej rozwiniętym na wspinanie się po jej szczeblach. Firmy, a w rezultacie również kraje, które poddały się temu procesowi, oferują wyższą jakość produktów przy wyższych płacach.

Założenia teorii Schumpetera zainspirowały badaczy ekonomii ewolucyjnej, którzy postrzegają innowację jako kreację nowych różnorodnych produktów w procesie „prób i błędów". Wybór nowych pomysłów i produktów determinowany jest według nich wzajemnym oddziaływaniem kompetencji firmy i jej otoczenia. We wszystkich z przedstawionych teorii brakuje jednego elementu, bardzo istotnego z punktu widzenia konkurencyjności regionalnej, a mianowicie wymiaru terytorialnego. Wprowadza go do literatury przedmiotu geografia ekonomiczna obejmująca trzy nurty w literaturze ekonomii: właściwą geografię ekonomiczną, ekonomię regionalną i nową geografię ekonomiczną. Rolę innowacji w rozwoju regionalnym podkreślają również dwie znaczące teorie - nowa teoria wzrostu i nowa teoria handlu. Ich podstawowe założenia i implikacje dla konkurencyjności regionalnej prezentuje tabela 1.

Związek między innowacjami i produktywnością jest przedmiotem licznych analiz poświęconych tematyce wzrostu gospodarczego. Ich autorzy podkreślają rolę innowacji jako czynnika wzrostu gospodarczego w długim okresie. Innowacje traktowane są jako proces tworzenia, rozwoju i wykorzystania nowych pomysłów, metod oraz technologii. Innowacje wpływają na poprawę konkurencyjności krajów i regionów na dwa sposoby. Po pierwsze, skutkują zmianami organizacyjnymi, metod produkcji oraz strategii marketingowych, czego efektem jest poprawa efektywności produkcji. Po drugie, wynikiem ich realizacji jest wprowadzenie na rynek nowych lub znacząco ulepszonych produktów. Znaczenie innowacji można rozpatrywać w wymiarze ekonomicznym, społecznym i kulturowym. Miernikami innowacyjności wykorzystywanymi najczęściej w analizach ekonomicznych są wydatki na dzia- 
łalność badawczo-rozwojową oraz patenty. Warto zauważyć, że chociaż często stosowane, poza licznymi zaletami oba mierniki mają również swoje wady. Pierwsze wcale nie muszą skutkować innowacjami, w przypadku drugich należy pamiętać o tym, że część wynalazków nie podlega opatentowaniu, a część już opatentowanych nie znajduje wykorzystania w praktyce. Istnieją liczne przykłady badań bazujących na funkcji Cobba-Douglasa, których wyniki potwierdzają pozytywny wpływ innowacji na poziom produktywności. Należą do nich m.in. analizy przeprowadzone dla Włoch (Parisi i in. 2005), Wielkiej Brytanii (Criscuolo, Haskel 2003), Brazylii (Gomez i in. 2003), Kanady (Gu, Tang 2003) czy Chile (Benavente 2002). Zestawienie wspomnianych i pozostałych wyników analiz oraz zależności między innowacjami i poziomem produktywności prezentuje E. Vieira i in. (2011, s. 7). W regionach słabiej rozwiniętych wzrost produktywności można osiągnąć poprzez zastosowanie obecnie istniejących technologii, w pozostałych utrzymanie przewagi konkurencyjnej wymaga stworzenia przez nie produktów najnowszej technologii (cutting-edge). Poprawa produktywności w regionie może być efektem nie tylko prowadzenia własnej działalności badawczo-rozwojowej i ponoszenia związanych z nią kosztów, ale również wynikiem wewnątrz- i międzyregionalnej dyfuzji (Rodrigez-Pose, Crescenzi 2008).

Tab. 1. Innowacje jako determinanta konkurencyjności regionalnej

\begin{tabular}{|c|c|c|c|}
\hline Teorie & Podstawowe założenia & $\begin{array}{c}\text { Determinanty } \\
\text { konkurencyjności }\end{array}$ & $\begin{array}{c}\text { Implikacje } \\
\text { dla konkurencyjności } \\
\text { regionalnej }\end{array}$ \\
\hline $\begin{array}{l}\text { Nowa } \\
\text { teoria } \\
\text { wzrostu }\end{array}$ & $\begin{array}{l}\text { - kapitał ludzki } \\
\text { jako czynnik produkcji, } \\
\text { - endogeniczny postęp techno- } \\
\text { logiczny jako czynnik wpły- } \\
\text { wający na wzrost gospodarczy } \\
\text { postęp technologiczny jako } \\
\text { efekt kumulacji wiedzy } \\
\text { i kapitału ludzkiego, } \\
\text { - rosnące korzyści akumulacji } \\
\text { wiedzy, } \\
\text { - efekty dyfuzji (spillover), } \\
\text {-zależność struktur regional- } \\
\text { nych od dotychczasowej ścież- } \\
\text { ki rozwoju (path dependency) } \\
\text { jako przeciwieństwo } \\
\text { ich celowego tworzenia nie- } \\
\text { jako od podstaw np. poprzez } \\
\text { system silnej polityki wsparcia } \\
\text { określonych dziedzin lub dzia- } \\
\text { łalności (path creation). }\end{array}$ & $\begin{array}{l}\text { - wydatki na działal- } \\
\text { ność badawczo- } \\
\text {-rozwojową, } \\
\text {-innowacyjność } \\
\text { (patenty), } \\
\text { - poziom edukacji, } \\
\text { - inwestycje w kapitał } \\
\text { ludzki, } \\
\text { - efektywne rozprze- } \\
\text { strzenianie wiedzy } \\
\text { (centra wiedzy). }\end{array}$ & $\begin{array}{l}\text { - różnice regionalne } \\
\text { w produktywności } \\
\text { i wzroście gospodar- } \\
\text { czym wynikają ze } \\
\text { zróżnicowania } \\
\text { w poziomie } \\
\text { technologicznym } \\
\text { i kapitale ludzkim, } \\
\text { - wymiana handlowa } \\
\text { może wspomagać } \\
\text { wzrost gospodarczy } \\
\text { i rozwój technolo- } \\
\text { giczny, } \\
\text { - konieczne są inwe- } \\
\text { stycje w działalność } \\
\text { badawczo-rozwojową } \\
\text { i kapitał ludzki } \\
\text { (szkolenia, trening). }\end{array}$ \\
\hline
\end{tabular}




\begin{tabular}{|c|c|c|c|}
\hline $\begin{array}{l}\text { Nowa } \\
\text { teoria } \\
\text { handlu }\end{array}$ & $\begin{array}{l}\text { - technologia jako bezpośredni } \\
\text { i endogeniczny czynnik } \\
\text { produkcji, } \\
\text { - postęp endogeniczny jako } \\
\text { rezultat inwestycji przedsię- } \\
\text { biorstw w prace B\&R, } \\
\text { innowacje i kapitał ludzki, } \\
\text {-tworzenie nowych technologii } \\
\text { oznacza malejące korzyści pły- } \\
\text { nące z zastosowania kapitału } \\
\text { i czynnika pracy, } \\
\text { - pozytywne efekty zewnętrzne } \\
\text { (externalities) związane } \\
\text { z produkcją nowych technolo- } \\
\text { gii podlegają procesowi ,rozle- } \\
\text { wania się” (spillover), } \\
\text { - wykorzystanie technologii ge- } \\
\text { neruje rosnące korzyści skali, } \\
\text { - pełna mobilność technologii } \\
\text { między firmami i krajami, } \\
\text { ograniczona mobilność } \\
\text { w zakresie wykorzystania tech- } \\
\text { nologii (koncepcja luki techno- } \\
\text { logicznej Findlay’a), } \\
\text {-założenie konkurencji } \\
\text { niedoskonałej. }\end{array}$ & $\begin{array}{l}\text { - czynniki umożliwia- } \\
\text { jące szybką realizację } \\
\text { korzyści skali } \\
\text { i wpływające } \\
\text { na przewagę „pierw- } \\
\text { szego gracza” (,first } \\
\text { mover” advantage), } \\
\text { - wykształcona siła } \\
\text { robocza, } \\
\text { - wyspecjalizowana } \\
\text { infrastruktura, } \\
\text { - sieć dostawców, } \\
\text {-lokalne technologie. }\end{array}$ & $\begin{array}{l}\text {-specjalizacja na } \\
\text { poziomie gałęzi jako } \\
\text { czynnik warunkujący } \\
\text { zewnętrzne korzyści } \\
\text { skali (Marshallian } \\
\text { economies of scale), } \\
\text { ten typ korzyści stanowi } \\
\text { bazę dla regionalnej } \\
\text { koncentracji przemysłu, } \\
\text { - wielkość lokalnego } \\
\text { rynku jako istotna deter- } \\
\text { minanta wewnętrznych } \\
\text { korzyści skali, } \\
\text {-inwestycje w czynniki } \\
\text { wpływające na przewa- } \\
\text { gę „pierwszego gracza” } \\
\text { postrzegane są jako } \\
\text { sprzyjające powsta- } \\
\text { waniu zewnętrznych } \\
\text { korzyści skali. }\end{array}$ \\
\hline
\end{tabular}

Źródło: Opracowanie własne na podstawie A Study on the factors of Regional Competitiveness. A Draft Final Report for the European Commission

Liczba analiz poświęconych innowacjom na poziomie regionu stale rośnie. Przyczyną tego jest rozwój teorii rozwoju regionalnego, wzrost zainteresowania innowacjami traktowanymi jako źródło przewag komparatywnych oraz poszukiwanie rozwiązań politycznych skutkujących zmniejszeniem dysproporcji regionalnych. Szczególną uwagę poświęca się regionalnym systemom innowacji. Działalność innowacyjna coraz rzadziej zamyka się w ramach pojedynczej firmy, a coraz częściej wymaga prowadzenia wspólnych działań. Przedsiębiorstwa zawdzięczają swoją innowacyjność nie tylko własnym zdolnościom organizacyjnym, ale również kontaktom z innymi przedsiębiorstwami (dostawcami, kontrahentami) oraz instytucjami. Komunikacja, współpraca i koordynacja stanowią obecnie niezbędne warunki dla tworzenia i dyfuzji technologii w regionie. Teoria regionalnych systemów innowacji bazuje na teorii dystryktów przemysłowych, nowej geografii ekonomicz-

${ }^{2} \mathrm{~W}$ teorii ekonomii podkreśla się występowanie tzw. zewnętrznych korzyści skali - ujemnej zależności pomiędzy kosztem jednostkowym produkcji od wielkości sektora w danej lokalizacji w odróżnieniu od wewnętrznych korzyści skali czyli spadku kosztu jednostkowego wraz ze wzrostem skali produkcji danego podmiotu. Marshallowskie pozytywne efekty zewnętrzne są często dzielone na te wynikające z przestrzennej bliskości firm produkujących podobne dobra - tzw. korzyści lokalizacji, oraz te wynikające ze skali ogółu działalności gospodarczej na danym obszarze - tzw. korzyści aglomeracji. 
nej, innowacyjnego otoczenia (Maeninig, Olschlager 2011), teorii klastrów oraz narodowych systemów innowacji (Asheim i in. 2011). Regionalny System Innowacji (RSI) można najprościej zdefiniować jako sieć współpracy pomiędzy organizacjami i instytucjami działającymi w regionie (centra transferu technologii, inkubatory przedsiębiorczości, banki, fundusze venture capital, ośrodki szkoleniowo-doradcze, uniwersytety, organy samorządu terytorialnego itd.), których celem jest wspieranie potencjału innowacyjnego przedsiębiorstw. To elastyczny i kreatywny socjoekonomiczny układ, który wykorzystuje regionalne atrybuty i zasoby adekwatnie do specyfiki i potrzeb regionalnego rynku.

Główną przesłanką budowy systemów jest nowe podejście do strategii rozwoju gospodarczego, ukierunkowane na poszukiwanie bezpiecznych i trwałych podstaw rozwoju wewnątrz regionów, przy szerokim zaangażowaniu środowisk lokalnych i regionalnych. Budowa systemu jest zdeterminowana regionalnie układem instytucjonalnym, poziomem rozwoju gospodarczego, zasobami, priorytetami strategii rozwoju oraz motywacją i wolą współdziałania. W ramach RSI podejmowane są przede wszystkim inicjatywy w zakresie transferu technologii, organizacyjnego i finansowego wspierania przedsięwzięć innowacyjnych, inicjowania powiązań sieciowych pomiędzy przedsiębiorstwami i administracją, podnoszenia jakości zasobów ludzkich oraz tworzenia elastycznych systemów wytwórczych w postaci dystryktów przemysłowych i klastrów. Te ostatnie definiowane jako geograficzna koncentracja firm prowadzących działalność w tych samych lub powiązanych branżach stanowią ważny komponent RSI (Asheim, Coenen 2005, s. 1174). Regionalne klastry są zjawiskiem spontanicznym, z kolei RIS posiada bardziej zaplanowany i systemowy charakter. Przejście od klastra do RSI wymaga wzmocnienia infrastruktury instytucjonalnej regionu. Kolejnym etapem jest powstanie regionu „uczącego się” (learning region, Morgan 2007). Koncepcja regionu „uczącego się” rozszerza koncepcję regionalnego systemu innowacji o zakres aktorów zaangażowanych w interaktywne uczenie się oraz ich silne „,zakorzenienie” w gospodarce lokalnej (locally embedded). Region uczący się to region, którego podmioty blisko współpracują ze sobą na poziomie instytucjonalnym po to, aby stworzyć i wdrożyć regionalne strategie innowacji. Rozwój wiedzy i sieci powiązań inspiruje lokalną/regionalną gospodarkę, jej przedsiębiorstwa, pracowników i instytucje do uczestnictwa w procesie „kolektywnego uczenia się”.

Innowacje potrzebują nowatorskiego otoczenia wspieranego przez sektor prywatny i publiczny, w szczególności nakładów na działalność badawczo-rozwojową generowanych przede wszystkim przez sektor prywatny, obecności instytucji badawczych i uniwersytetów, ich współpracy z przemysłem oraz ochrony własności intelektualnej (The Global Competitiveness Report, 2010-2011). Poziom innowacji w regionie zależy jednak nie tylko od atrybutów regionu w postaci funkcjonujących w jego ramach instytucji czy sieci powiązań firm, ale również od stopnia „lokalnego zakorzenienia” przedsiębiorstw. Otoczenie lokalne determinuje proces innowacji i jednocześnie decyduje o rozmiarze korzyści, jakie czerpie z niego region. Rysunek 1 prezentuje wzajemne zależności między otoczeniem lokalnym i procesem innowacji. Większość analiz dotyczących innowacji na poziomie regionalnym skupia się na zależnościach przedstawionych w górnej części rysunku: innowacja w firmie A jest rezultatem oddziaływania otoczenia i zasobów wewnętrznych firmy w postaci kapitału ludzkiego, zasobów technicznych oraz działalności badawczo-rozwojowej. Czynniki zewnętrzne można podzielić na trzy grupy: otoczenie lokalne i instytucje, czynniki nielokalne tego samego typu oraz powiązania rynkowe i sprzężenia zwrotne. W każdym przypad- 


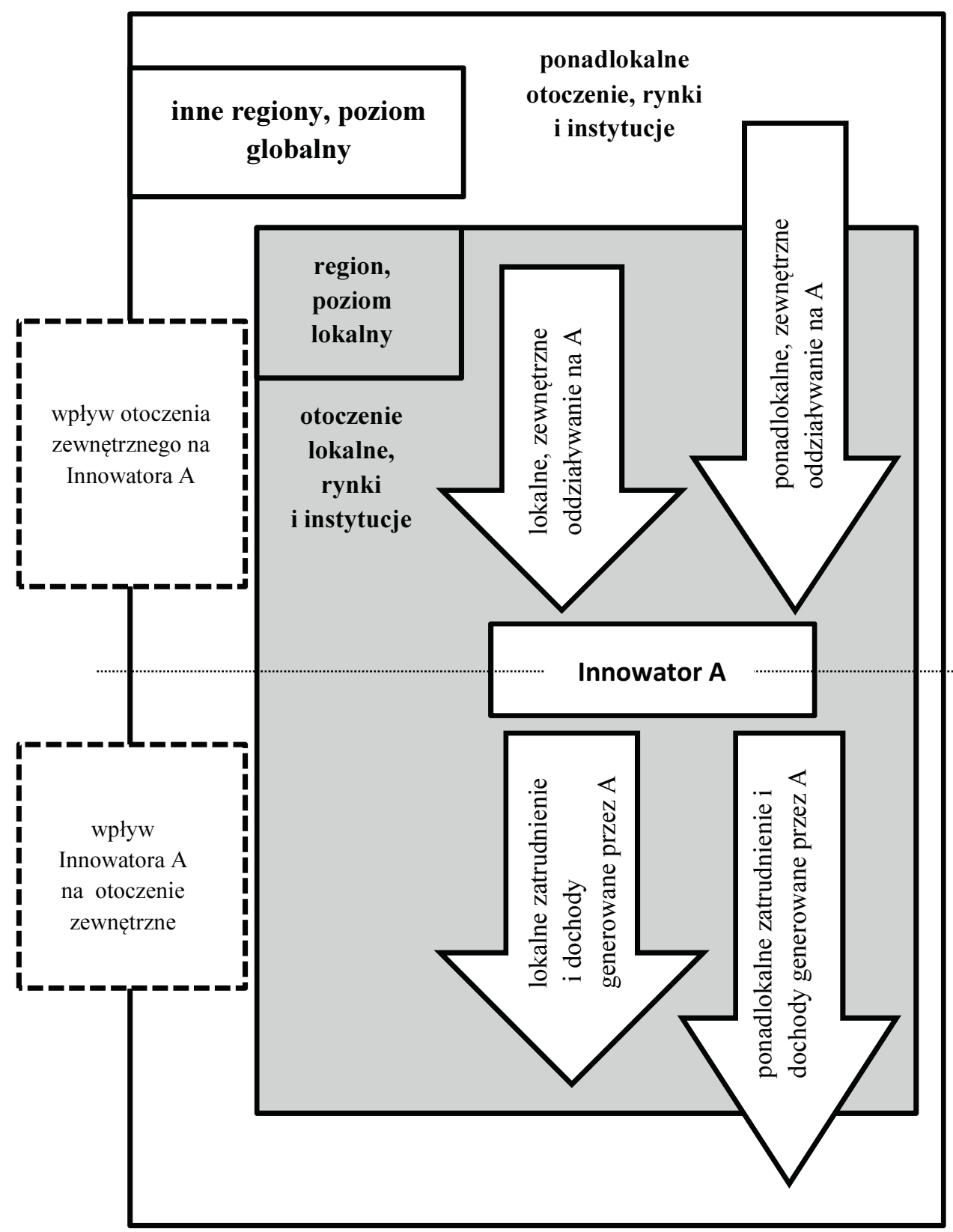

Rys. 1. Innowacje a rozwój regionalny

Źródło: Shearmur, Bonnet 2011, s. 6 
ku efekt oddziaływania czynników zewnętrznych zależy od zdolności absorpcyjnych firmy, silnie powiązanych z jej zasobami wewnętrznymi.

Znacznie mniej analiz odnosi się do drugiej części rysunku, tj. do wpływu innowacji na gospodarkę lokalną/regionalną i poza-lokalną/poza-regionalną. Pomimo faktu, że rozwojowi lokalnemu często towarzyszy wzrost innowacyjności lokalnych przedsiębiorstw nie można zapominać o tym, że te same innowacje mogą powodować spadek zatrudnienia i dochodów lokalnej społeczności i tym samym spadek konkurencyjności analizowanego regionu. To, czy tak się stanie zależy od stopnia „lokalnego zakorzenienia” firm. Im większa lokalna gospodarka, tym większe prawdopodobieństwo, że innowacyjne firmy pozyskają zasoby (kapitał ludzki, technologię itp.) konieczne do wykorzystania i rozwoju swoich innowacji, zapewniając tym samym korzystny wpływ na gospodarkę. Obok wielkości gospodarki regionalnej istotną rolę odgrywają również dostępność rynków, struktura przemysłowa oraz koszty. Wszystkie te czynniki determinują wprowadzenie innowacji w fazę produkcji - etap, od którego zależy wzrost zatrudnienia i dochodów w regionie. Innymi słowy, jeśli firma wprowadzająca innowacje musi poszukiwać rynków, pracowników czy odbiorców poza regionem celem rozwoju swojej produkcji, innowacja - w najlepszym przypadku - nie wpłynie na rynek lokalny. Spadek zatrudnienia może nastąpić w branżach, które znajdują się w ostatniej fazie cyklu życia produktu, co wynika z wpływu innowacji na wzrost produktywności. Dla gospodarki zmiana ta może okazać się korzystna, ponieważ jej efektem jest relokacja czynników do bardziej produktywnych branż w regionie i tym samym jej wzrost. W przypadku mniejszego regionu lokalna gospodarka nie jest w stanie generować wystarczającej liczby alternatywnych miejsc pracy. Tu innowacje mogą prowadzić do spadku zatrudnienia i obniżenia dynamiki wzrostu regionu. Jeśli region potrafi tylko generować innowacje, a nie może stworzyć warunków do uruchomienia procesu „kreatywnej destrukcji”, nie osiągnie korzyści ekonomicznych będących wynikiem poprawy innowacyjności.

Poziom innowacyjności decyduje przede wszystkim o konkurencyjności najbardziej rozwiniętych gospodarek regionalnych. Mowa tu o regionach określanych jako źródła wiedzy, charakteryzujących się wysoką gęstością zaludnienia (wskazującą na formowanie się gospodarek zurbanizowanych) oraz wysokim i trwałym wzrostem PKB per capita. Cechą charakterystyczną tych regionów są duże wydatki na działalność badawczo-rozwojową, wysoki wskaźnik nowopowstałych firm, najwyższe wśród regionów dopasowanie popytu i podaży siły roboczej oraz duża liczba rejestrowanych patentów.

\section{ANALIZA EMPIRYCZNA}

Analizą objęto 35 regionów NUTS 2 w ostatnim, czwartym etapie procesu transformacji, w latach 1999-2008. Jest to etap transformacji, w którym analizowane kraje w największym stopniu ujednoliciły swoje ścieżki rozwoju. Przyjęcie takiego okresu badawczego wynika jednocześnie z braku pełnych, aktualnych i porównywalnych danych na poziomie regionalnym w kolejnych latach. W analizie porównawczej pominięto kolejne lata również z innego powodu, mianowicie odczuwanych w różnym stopniu przez analizowaną grupę krajów skutków kryzysu finansowego. Badanie na poziomie regionów przeprowadzone zostało w oparciu o dane pochodzące z bazy danych Eurostat (Regional Statistics) i OECD (OECD 
Regional Database). Z uwagi na dostępność danych na poziomie regionalnym, badaniem objęto dwa obszary innowacyjności, tj. tworzenie wiedzy i zasoby ludzkie. Za miernik konkurencyjności przyjęto poziom i dynamikę PKB per capita.

Na łączną liczbę analizowanych regionów składa się 16 regionów polskich, 8 czeskich, 7 węgierskich i 4 słowackie. Pod względem gospodarczym analizowane regiony wykazują zarówno podobieństwa jak i różnice. Pierwsze wynikają ze wspólnej przeszłości i realizowanego przez dekady modelu gospodarki socjalistycznej, drugie związane są z różnicami kulturowymi, w systemach prawnych czy wreszcie w strukturach przestrzennych uformowanych jako rezultat długotrwałych procesów (Gorzelak, Jałowiecki 2002). Transformacja i rozwój regionalny pozostają w ścisłym związku. Zmiany w strukturze gospodarczej regionów zależą w dużej mierze od zmian strukturalnych w całej gospodarce. W krajach postsocjalistycznych różnice w poziomie rozwoju regionalnego stanowią wypadkową sytuacji wyjściowej i procesu jej zmian. Analiza regionów Europy Środkowej i Wschodniej pod względem ich reakcji na proces transformacji systemowej pozwala na wyróżnienie czterech grup (Gorzelak 2009, s. 5). Pierwszą tworzą „Liderzy”, tj. regiony metropolitalne, które w okresie socjalizmu stanowiły ośrodki systemów terytorialnych. Poddane w procesie transformacji restrukturyzacji, w tym deindustrializacji, były w stanie zaoferować najlepsze warunki lokalizacji dla najbardziej dynamicznych sektorów (usług finansowych, usług w zakresie zarządzania, turystyki czy handlu). Wynikało to przede wszystkim z ich zdywersyfikowanej struktury gospodarczej. Obecnie dochody, podobnie jak standard życia mieszkańców są tu najwyższe. „Przegrani” to stare regiony przemysłowe, z których niektóre przed transformacją odgrywały większą rolę niż duże ośrodki miejskie. Ich cechą charakterystyczną był swoisty dualizm: z jednej strony silnie zurbanizowane, $\mathrm{z}$ drugiej strony „dziedzictwo przemysłowe” thumiło ich miejski charakter. Ich zdywersyfikowane gospodarki pozwoliły na rozwój działalności gospodarczej, który bazował głównie na niskich kwalifikacjach siły roboczej i przeciążonej infrastrukturze. W rezultacie restrukturyzacja okazała się tu długotrwałym procesem i dopiero w ostatnim czasie regiony te wkroczyły na ścieżkę wzrostu. Kolejna grupa regionów to „Zwycięzcy”. Tworzy ją zaledwie kilka regionów, których potencjał nie był doceniany w gospodarce socjalistycznej. To w przypadku krajów Grupy Wyszehradzkiej przeważnie regiony turystyczne, cieszące się największą popularnością wśród turystów krajowych i zagranicznych. W niektórych z nich nastąpił proces reindustrializacji, głównie za sprawą napływu kapitału zagranicznego. Kilka regionów przygranicznych odniosło korzyści ze swojej lokalizacji w efekcie prowadzonej nielegalnie wymiany handlowej. Nie dotyczy to jednak Grupy Wyszehradzkiej, w której lokalizacja przygraniczna stanowi barierę rozwoju regionów. Ostatnią grupę tworzą w większości krajów Europy Środkowej i Wschodniej najsłabiej rozwinięte i pozbawione aglomeracji miejskich regiony wschodnie i przygraniczne. Ich słaby rozwój uwarunkowany jest historycznie podziałem Europy Środkowej na dwie części wpływów: Wschodu i Zachodu. Istotne różnice w rozwoju regionów wschodnich i zachodnich szczególnie widoczne są w krajach Grupy Wyszehradzkiej.

Badane regiony wykazują istotne zróżnicowanie w aspekcie historycznym, geograficznym, demograficznym, ekonomicznym i społecznym. Tabela 2 przedstawia wielkość, gęstość zaludnienia oraz poziom i dynamikę PKB per capita we wszystkich analizowanych regionach NUTS 2. Regiony różnią się powierzchnią i liczbą mieszkańców. W samym województwie mazowieckim mieszka prawie tyle samo osób co na całej Słowacji, a w trzech polskich województwach więcej niż w Czechach czy na Węgrzech. Wśród analizowanych 
regionów najniższą gęstością zaludnienia charakteryzują się województwo podlaskie i warmińsko-mazurskie. Do regionów, których gęstość zaludnienia przekracza średnią krajową należą: Praha, Strední Morava i Moravskoslezsko w Czechach, Közép-Magyarország na Węgrzech, Bratislavský kraj i Západné Slovensko na Słowacji oraz województwa: łódzkie, mazowieckie, małopolskie, śląskie i dolnośląskie. Tradycyjnie, największą gęstością zaludnienia charakteryzują się regiony stołeczne, w szczególności region Pragi.

Tab. 2. Charakterystyka regionów NUTS 2 w krajach Grupy Wyszehradzkiej

\begin{tabular}{|c|c|c|c|c|c|}
\hline Państwo & NUTS 2 & $\begin{array}{l}\text { Obszar } \\
(\mathrm{km} \mathrm{2})\end{array}$ & $\begin{array}{c}\text { Gęstość } \\
\text { zaludnienia } \\
2008 \text { r. }\end{array}$ & $\begin{array}{c}\text { PKB } \\
\text { per capita } \\
1999 \mathrm{r} . \\
\text { (EUR) }\end{array}$ & $\begin{array}{c}\text { Dynamika PKB } \\
\text { per capita } \\
\text { 1999-2008 } \\
\text { (średnia)* }^{*}\end{array}$ \\
\hline \multirow[t]{9}{*}{ Czechy } & & 78866,7 & 132 & 5500 & 0,105 \\
\hline & Praha & 496,1 & 2443 & 10700 & 0,116 \\
\hline & Strední Cechy & 11014,8 & 109 & 5100 & 0,105 \\
\hline & Jihozápad & 17618 & 68 & 5100 & 0,095 \\
\hline & Severozápad & 8649 & 132 & 4600 & 0,097 \\
\hline & Severovýchod & 12440,1 & 120 & 4900 & 0,094 \\
\hline & Jihovýchod & 13991,3 & 118 & 4900 & 0,108 \\
\hline & Strední Morava & 9230,4 & 134 & 4500 & 0,102 \\
\hline & Moravskoslezsko & 5427 & 230 & 4400 & 0,113 \\
\hline \multirow[t]{8}{*}{ Węgry } & & 93029 & 108 & 4400 & 0,098 \\
\hline & Közép-Magyarország & 6918,3 & 419 & 6700 & 0,107 \\
\hline & Közép-Dunántúl & 11116,2 & 99 & 4100 & 0,093 \\
\hline & Nyugat-Dunántúl & 11328,2 & 88 & 5100 & 0,078 \\
\hline & Dél-Dunántúl & 14168,7 & 68 & 3400 & 0,085 \\
\hline & Észak-Magyarország & 13431 & 92 & 2900 & 0,090 \\
\hline & Észak-Alföld & 17728,8 & 85 & 2800 & 0,095 \\
\hline & Dél-Alföld & 18337,8 & 73 & 3300 & 0,085 \\
\hline \multirow[t]{11}{*}{ Polska } & & 312685 & 122 & 4100 & 0,093 \\
\hline & łódzkie & 18219 & 140 & 3700 & 0,098 \\
\hline & mazowieckie & 35559 & 146 & 6400 & 0,095 \\
\hline & małopolskie & 15190 & 216 & 3600 & 0,091 \\
\hline & śląskie & 12331 & 377 & 4400 & 0,095 \\
\hline & lubelskie & 25121 & 86 & 2900 & 0,091 \\
\hline & podkarpackie & 17844 & 118 & 3000 & 0,088 \\
\hline & świętokrzyskie & 11708 & 109 & 3200 & 0,096 \\
\hline & podlaskie & 20187 & 59 & 3000 & 0,094 \\
\hline & wielkopolskie & 29826 & 114 & 4300 & 0,093 \\
\hline & zachodniopomorskie & 22896 & 74 & 4100 & 0,082 \\
\hline
\end{tabular}




\begin{tabular}{|l|l|r|r|r|l|}
\hline \multirow{5}{*}{} & lubuskie & 13989 & 72 & 3700 & 0,088 \\
\cline { 2 - 6 } & dolnośląskie & 19948 & 144 & 4300 & 0,096 \\
\cline { 2 - 6 } & opolskie & 9412 & 110 & 3400 & 0,096 \\
\cline { 2 - 6 } & kujawsko-pomorskie & 17970 & 115 & 3600 & 0,091 \\
\cline { 2 - 6 } & warmińsko-mazurskie & 24192 & 59 & 3200 & 0,089 \\
\cline { 2 - 6 } & pomorskie & 18293 & 121 & 4200 & 0,085 \\
\hline \multirow{5}{*}{ Słowacja } & & 49034,7 & 110 & 3600 & 0,133 \\
\hline & Bratislavský kraj & 2052,6 & 298 & 7600 & 0,143 \\
\cline { 2 - 6 } & Západné Slovensko & 14992,5 & 124 & 3400 & 0,134 \\
\cline { 2 - 6 } & Stredné Slovensko & 16263,2 & 83 & 2900 & 0,134 \\
\cline { 2 - 6 } & Východné Slovensko & 15726,4 & 100 & 2700 & 0,126 \\
\hline
\end{tabular}

Źródło: opracowanie własne na podstawie danych Eurostat

*średnia dynamika PKB per capita liczona jako $\ln (\mathrm{Yn} / \mathrm{Yo}) / \mathrm{n}$

Źródło: opracowanie własne na podstawie danych OECD iLibrary

**Na poziomie NUTS 3 w ramach obszaru Czech wyróżniamy 14 regionów (13 „krajów” i Pragę), które posiadają ograniczoną polityczną i gospodarczą autonomię. Węgry podzielone są na 19 megyek (okręgi/hrabstwa, jednostki NUTS 3) i Budapeszt, które od 1996 r. tworzą 7 jednostek NUTS 2. Polska podzielona jest na 66 podregionów NUTS 3 (do 2008 roku 45 jednostek). Podział Słowacji na 8 krajów dysponujących ograniczoną autonomią miał miejsce w 2002 roku

Do regionów o najwyższym standardzie życia w 2008 roku, mierzonym poziomem PKB per capita, należały poza regionami stołecznymi: Strední Cechy, Jihovýchod i Moravskoslezsko w Czechach, Nyugat-Dunántúl i Közép-Dunántúl na Węgrzech, śląskie i dolnośląskie w Polsce oraz Západné Slovensko na Słowacji. Regiony wykazują bardzo duże zróżnicowanie w zakresie standardu życia. Lokalizację regionów w krajach Grupy Wyszehradzkiej, regionalne PKB per capita w 1999 r. oraz dynamikę wzrostu gospodarczego w analizowanym okresie przedstawia mapa 1. W regionie Pragi PKB per capita było prawie trzykrotnie wyższe niż w regionie północno-zachodnim (Severozápad) czy Centralnej Morawie (Strední Morava). Jeszcze większe różnice występowały na Słowacji pomiędzy regionem stołecznym a regionem wschodnim (Východné Slovensko). W analizowanym okresie we wszystkich regionach Grupy Wyszehradzkiej nastąpił wzrost PKB per capita. Grupę województw o najniższej dynamice tworzyły polskie województwa. Najwyższą dynamiką w całej grupie charakteryzowały się regiony Słowacji oraz region Pragi i Moravskoslezsko.

W latach 1999-2008 w czterech analizowanych krajach zróżnicowanie poziomu rozwoju gospodarczego na poziomie NUTS 2 wzrosło. Potwierdza to wartość współczynnika dyspersji PKB publikowanego przez Eurostat. W Polsce i Czechach, pomimo wzrostu, zróżnicowanie nadal pozostaje niższe od przeciętnego w UE-27 (por. wykres 1). Najwyższe zróżnicowanie regionalne występuje na Węgrzech (prawie 38,3\% w 2008 roku).

Interpretując zróżnicowanie regionalne należy mieć na uwadze podział terytorialny krajów. Podział na małe jednostki i ich niewielka liczba sprzyjają wyższym wskaźnikom koncentracji. Zależność ta tłumaczy najmniejsze dysproporcje regionalne w Polsce. Za istotny czynnik zróżnicowania regionalnego należy uznać delimitację regionu stołecznego, zwłaszcza jeśli stolica dominuje gospodarczo w kraju, w którym liczna jednostek NUTS 2 jest 
nieliczna. Skrajny przypadek stanowi Słowacja, gdzie kontrast pomiędzy regionem bratysławskim a resztą kraju jest wyjątkowo duży. Przewaga Pragi w Czechach jest również bardzo widoczna, przede wszystkim w zakresie PKB per capita, jednak ze względu na wyższy poziom rozwoju kraju nie jest tak duża jak Bratysławy na Słowacji. Dominacja Budapesztu jest jeszcze mniejsza. Na tle reszty krajów przewaga województwa mazowieckiego nad pozostałymi regionami Polski jest zdecydowanie najmniejsza. Analiza rozpiętości w zakresie PKB per capita między pierwszym i drugim a drugim i ostatnim regionem każdego z krajów Grupy Wyszehradzkiej pokazuje, że zróżnicowanie regionalne poza regionami stołecznymi nie jest już takie duże. Warto zauważyć, że podobnie jak w pozostałych krajach UE brak jest prostego związku między stopniem zróżnicowania regionalnego a poziomem rozwoju gospodarczego analizowanych krajów (Domański i in. 2003).

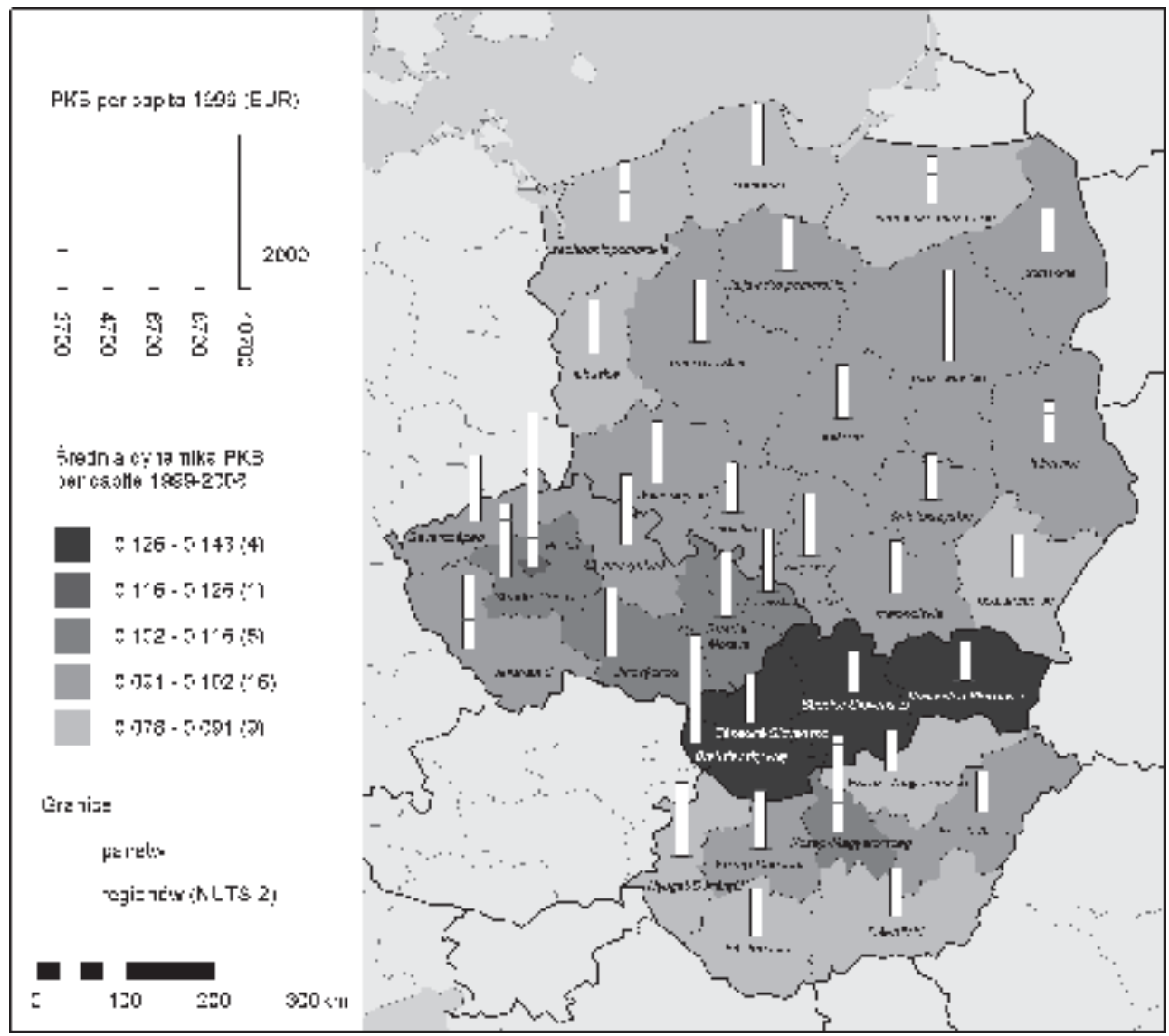

Mapa 1. Zróżnicowanie regionalne PKB per capita i dynamiki PKB per capita w krajach Grupy Wyszehradzkiej, 1999-2008

Źródło: opracowanie własne na podstawie danych Eurostat

Analiza wskaźników prezentowanych w tabeli 2 pozwala na podjęcie próby wytypowania regionów określanych jako źródła wiedzy. Zgodnie z założeniami przyjętymi w części 
teoretycznej, zaliczyć do nich można region Pragi i Moravskoslezsko w Czechach, Közép-Magyarország i Centralna Transdanubia (Közép-Dunántúl) na Węgrzech, Bratislavský kraj i Západné Slovensko na Słowacji oraz województwa mazowieckie, śląskie i dolnośląskie (por. mapa 2). Są to regiony, o których konkurencyjności decyduje przede wszystkim poziom innowacyjności. Wyniki analizy potwierdzają (poza województwem śląskim) wyższe wydatki na działalność badawczo-rozwojową oraz większą liczbę zgłoszeń patentowych w regionach wytypowanych jako źródła wiedzy. W pierwszej dziesiątce regionów o najniższym, nie przekraczającym $0,3 \%$ PKB poziomie wydatków na działalność badawczo-rozwojową znalazło się aż siedem polskich województw (świętokrzyskie, lubuskie, opolskie, zachodniopomorskie, warmińsko-mazurskie, podlaskie i kujawsko-pomorskie) oraz Severozápad, Észak-Magyarország i Východné Slovensko. Kraje Europy Środkowej i Wschodniej znacznie odbiegają od przeciętnych wartości nakładów w krajach OECD i w Unii Europejskiej. Stosunkowo największą część środków na badania i rozwój przeznacza Republika Czeska - niemal 1,3\% PKB. Polska i Słowacja maja zbliżony poziom nakładów na badania i rozwój, utrzymujący się na poziomie $0,6 \%$ PKB. Na Węgrzech na badania i rozwój przeznaczany jest niecały $1 \%$ PKB.

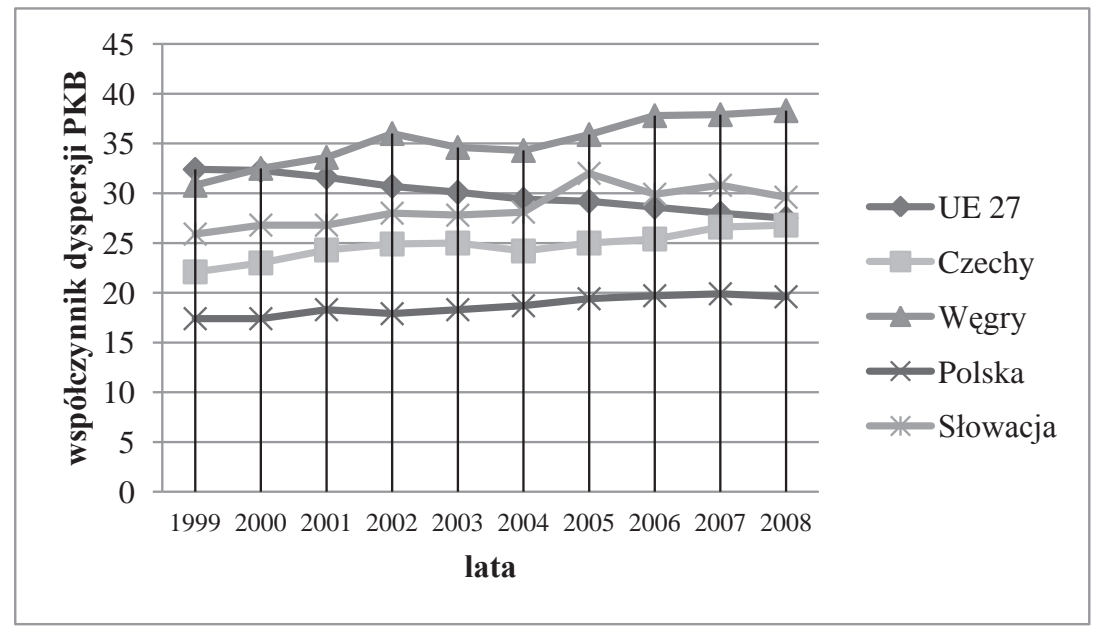

Wyk. 1. Współczynnik dyspersji PKB w krajach Grupy Wyszehradzkiej, 1999-2008

Źródło: opracowanie własne na podstawie danych Eurostat

Kolejnym wskaźnikiem pozwalającym na określenie poziomu innowacyjności kraju i regionu jest liczba patentów. Największą liczbą zgłoszeń patentowych EPO mogły się poszczycić Węgry i Czechy, odpowiednio 12 i $10 \mathrm{w}$ przeliczeniu na milion mieszkańców. Na Słowacji wskaźnik ten wyniósł niemal 5, a w Polsce zaledwie 3. Do liderów należały regiony stołeczne Węgier (30) i Czech (20). Dla porównania w województwie mazowieckim wskaźnik ten wyniósł niecałe 5 patentów w przeliczeniu na milion mieszkańców. Grupę regionów o najmniejszej liczbie zgłoszeń patentowych tworzyły polskie województwa i Stredné Slovensko. Analiza struktury zgłoszeń patentowych EPO potwierdziła jeszcze jedną niekorzystną dla regionów Grupy Wyszehradzkiej prawidłowość, mianowicie bardzo 
niski udział patentów w dziedzinach wysokich technologii. W dwóch krajach będących liderami w zakresie liczby zgłoszeń patentowych, czyli na Węgrzech i w Czechach, wskaźnik ten wyniósł odpowiednio zaledwie 2,9 i 1,1 w przeliczeniu na milion mieszkańców. Na Słowacji było to 0,8 , a w Polsce o połowę mniej. Do liderów należał region stołeczny Węgier $(7,8)$, Słowacji $(5,2)$ i Czech $(3,7)$.

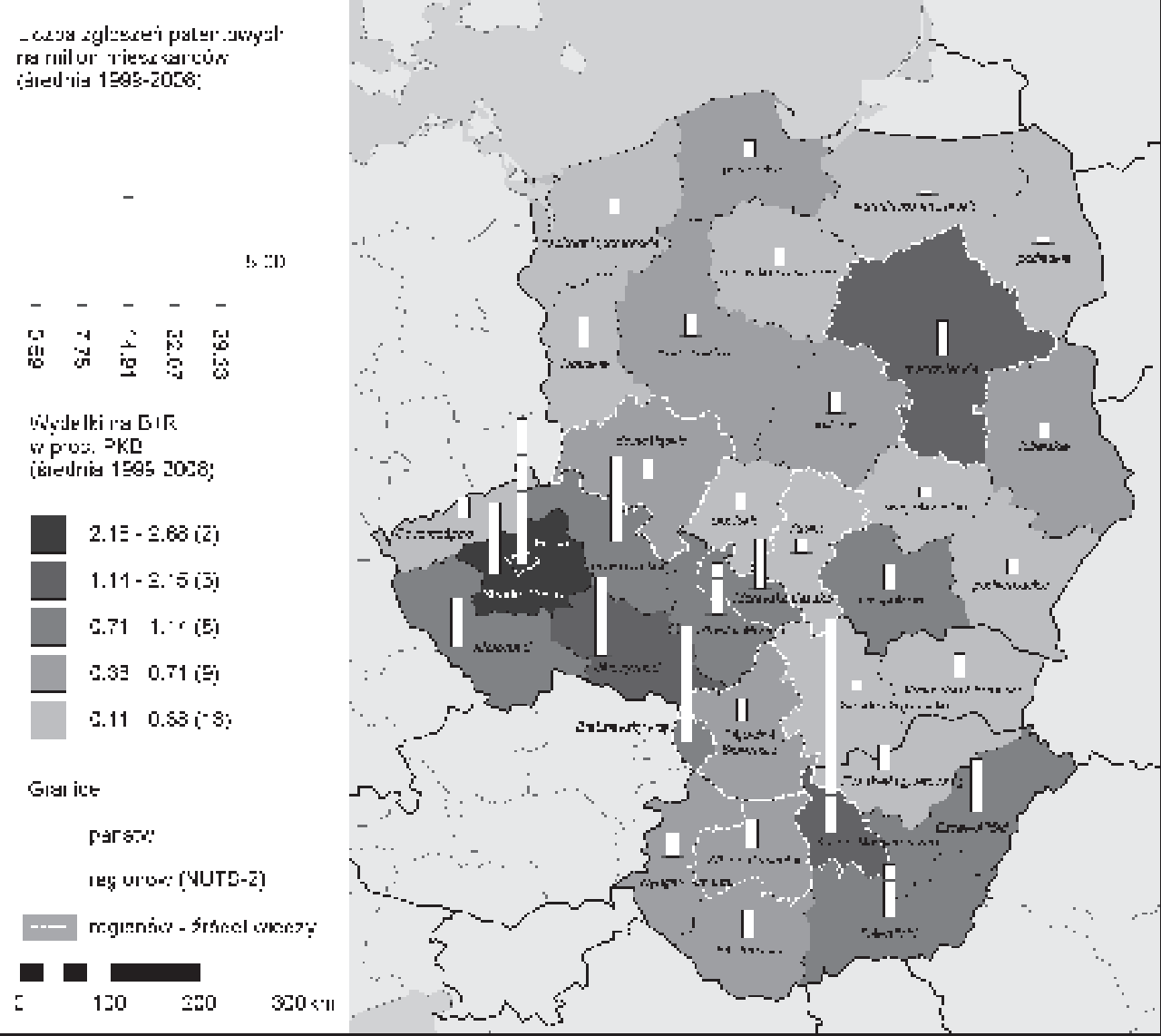

Mapa 2. Wydatki na działalność badawczo-rozwojową i zgłoszenia patentowe w latach 1999-2008

Źródło: opracowanie własne na podstawie danych Eurostat

*Z powodu braku danych, w przypadku Czech średnie wydatki na działalność badawczo-rozwojową obliczono dla okresu 2001-2008, a Polski i Słowacji za lata 2000-2008

Zestawienie średniego poziomu i dynamiki wydatków na działalność badawczo-rozwojową pokazuje, że niestety najbardziej liczną grupę regionów stanowią NUTS 2, w których na badania i rozwój przeznacza się średnio mniej niż 0,5\% PKB (20 regionów). Połowę tej grupy stanowią z kolei regiony, w których zanotowano dodatkowo spadek wydatków na działalność badawczo-rozwojową w stosunku do generowanego przez nie PKB (por. wy- 
kres 2). W całej Grupie Wyszehradzkiej w latach 2001-2008 wzrost wydatków na B+R w stosunku do PKB zanotowało łącznie 19 regionów, wśród których nie znalazł się ani jeden region słowacki. Najwyższy wzrost odnotowało województwo świętokrzyskie, dwa regiony węgierskie: Észak-Magyarország (Północne Węgry) i Észak-Alföld (Północna Wielka Nizina Węgierska) oraz dwa czeskie: region południowo-zachodni (Jihozápad) i Centralna Morawa (Strední Morava).

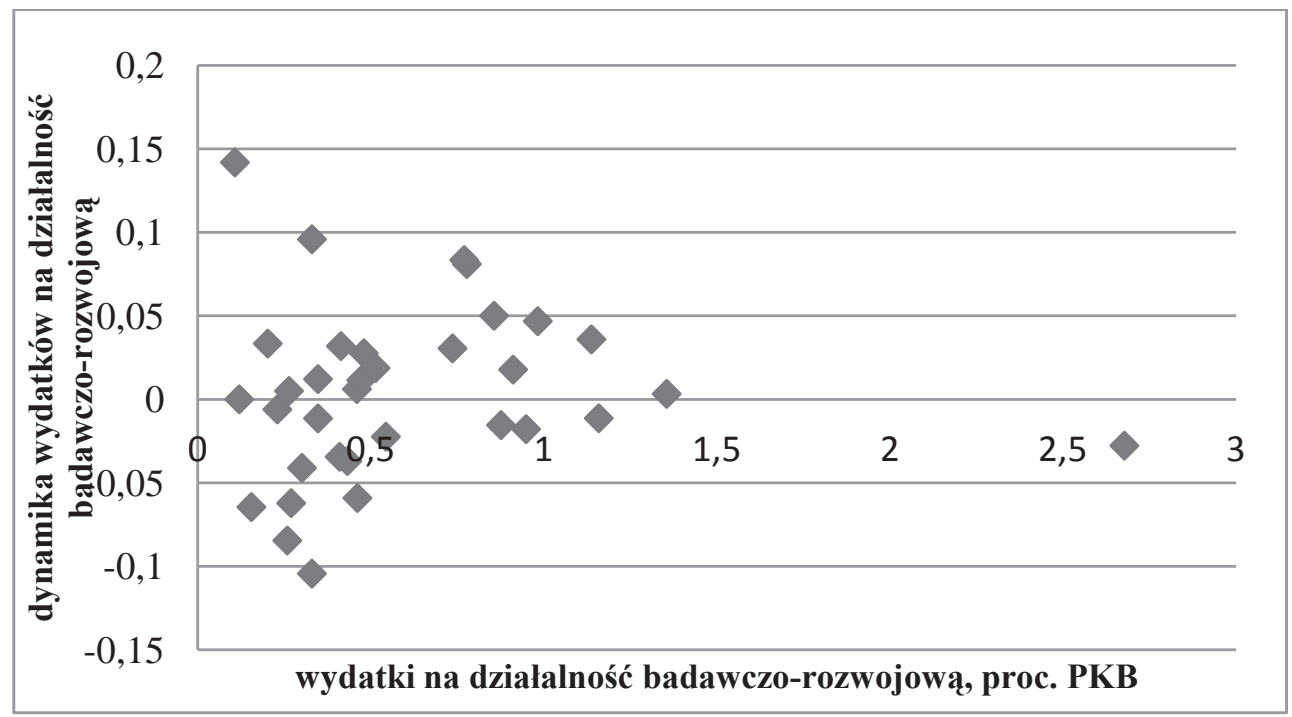

$W y k$. 2. Średni poziom i średnia dynamika wydatków na działalność badawczo-rozwojową* (\% PKB) w regionach NUTS 2, 2001-2008*

Źródło: opracowanie własne na podstawie danych Eurostat

* średnia dynamika wydatków liczona jako $\ln (\mathrm{Xn} / \mathrm{Xo}) / \mathrm{n}$, z uwagi na brak części danych za rok 1999 i 2000 , okres analizy ograniczono do lat 2001-2008

Znaczenie nakładów na działalność badawczo-rozwojową w aspekcie ekonomicznym zależy w dużej mierze od struktury ich finansowania i wydatkowania. Bardzo ważne jest zatem to, w jakim zakresie tworzenie postępu technologicznego finansowane jest przez przedsiębiorstwa, a w jakim ze środków publicznych (z budżetu państwa). Analizując strukturę finansowania nakładów na badania i rozwój w krajach i regionach Grupy Wyszehradzkiej, możemy zauważyć dominację środków publicznych pochodzących z budżetu państwa. Najwyższy udział przedsiębiorstw w wydatkach na B+R, mierzony procentem PKB, zanotowano w czeskich regionach. W regionie Strední Cechy osiągnął on wartość 2,39\% PKB, przekraczając niemal dwukrotnie średnią UE-27. Najniższy wskaźnik odnotowały polskie województwa, z zachodniopomorskim jako anty-liderem na czele $(0,02 \%$ PKB). Zestawienie 10 regionów o najwyższym i najniższym udziale wydatków na działalność badawczo-rozwojową w sektorze przedsiębiorstw prezentuje tabela 3 . W pozostałych regionach, które stanowią największą grupę, finansowanie ze strony firm oscyluje w przedziale zaledwie 0,15-0,30\% PKB. Zbyt niski udział przedsiębiorstw w finansowaniu prac badawczo-rozwojowych może być tłumaczony brakiem zainteresowania lub brakiem środków finansowych, 
jak również brakiem kooperacji z ośrodkami badawczymi spowodowanym m.in. niedopasowaniem prowadzonej działalności badawczej do potrzeb i wymogów prywatnych przedsiębiorców (Rozmus, Cyran 2009). W Polsce niski poziom nakładów świadczy również o braku mechanizmów podatkowych, skłaniających firmy do ponoszenia omawianych kosztów (Bąk i in. 2004).

Tab. 3. Regiony o najwyższym i najniższym udziale wydatków na działalność badawczo-rozwojową w sektorze przedsiębiorstw, w proc. PKB

\begin{tabular}{|l|l|}
\hline $\begin{array}{c}\text { Regiony o najwyższym i najniższym } \\
\text { udziale wydatków na działalność } \\
\text { badawczo-rozwojową } \\
\text { w sektorze przedsiębiorstw }\end{array}$ & $\begin{array}{c}\text { Regiony o najniższym udziale wydatków } \\
\text { na działalność badawczo-rozwojową } \\
\text { w sektorze przedsiębiorstw }\end{array}$ \\
\hline Strední Cechy: 2,39 & Észak-Magyarország: 0,13 \\
\hline Praha: 0,87 & Wielkopolskie: 0,12 \\
\hline Severovýchod: 0,80 & Łódzkie: 0,12 \\
\hline Moravskoslezsko: 0,70 & Lubelskie: 0,10 \\
\hline Strední Morava: 0,67 & Dél-Dunántúl: 0,06 \\
\hline Közép-Magyarország: 0,63 & Świętokrzyskie: 0,05 \\
\hline Jihovýchod: 0,58 & Lubuskie: 0,04 \\
\hline Jihozápad: 0,46 & Opolskie: 0,04 \\
\hline Západné Slovensko: 0,38 & Warmińsko-Mazurskie: 0,03 \\
\hline Mazowieckie: 0,34 & Zachodniopomorskie: 0,02 \\
\hline
\end{tabular}

Źródło: opracowanie własne na podstawie danych Eurostat

Analiza danych potwierdziła średni poziom korelacji między dynamiką PKB per capita a poziomem wydatków na działalność badawczo-rozwojową oraz łączną liczbą zgłoszeń patentowych EPO na milion mieszkańców. Współczynniki korelacji Pearsona wyniosły odpowiednio 0,29 i 0,37. Omówione zależności przedstawione na wykresach 3 i 4 pozwalają na domniemanie wpływu innowacji na dynamikę PKB per capita i tym samym konkurencyjność regionalną w krajach Grupy Wyszehradzkiej.

Wzrostowi konkurencyjności regionów Grupy Wyszehradzkiej mierzonemu dynamiką PKB per capita towarzyszył spadek bezrobocia. Wyjątek stanowiły cztery regiony Węgier i jeden słowacki: Stredné Slovensko. Mowa tu o najuboższych regionach Węgier: DélDunántúl, Észak-Magyarország, Észak-Alföld i Dél-Alföld. Oznacza to, że w większości regionów wzrostowi wydatków na $\mathrm{B}+\mathrm{R}$ nie towarzyszył wzrost regionalnego bezrobocia. Wśród dziesięciu regionów o najwyższym spadku stopy bezrobocia znalazło się aż osiem regionów polskich (lubuskie, mazowieckie, pomorskie, warmińsko-mazurskie, podlaskie, dolnośląskie, zachodniopomorskie i podkarpackie) oraz Jihozápad i Strední Cechy.

Według Regional Innovation Scoreboard 2009 poziom innowacyjności regionów stołecznych Węgier, Czech i Słowacji nie odbiega od średniego poziomu w UE. W Polsce wyróżniono dwie grupy regionów: o niskim i średnio-niskim poziomie innowacyjności. Województwo mazowieckie zaliczono do drugiej grupy. We wszystkich polskich regio- 
nach najniżej oceniono działalność innowacyjną przedsiębiorstw (wydatki na B+R, liczba patentów, innowacyjne MSP), a najwyżej poziom wykształcenia i publiczne finansowanie działalności badawczo-rozwojowej. Na Węgrzech, poza regionami sklasyfikowanymi jako źródła wiedzy, za przyczynę słabych wyników uznano, podobnie jak w Polsce, ograniczoną działalność innowacyjną w przedsiębiorstwach oraz słabe efekty działalności innowacyjnej w postaci stworzonych technologii i liczby innowatorów. W Czechach i na Słowacji za relatywną siłę regionów, poza stołecznymi, uznano wykształcenie i publiczne wydatki na działalność rozwojową.

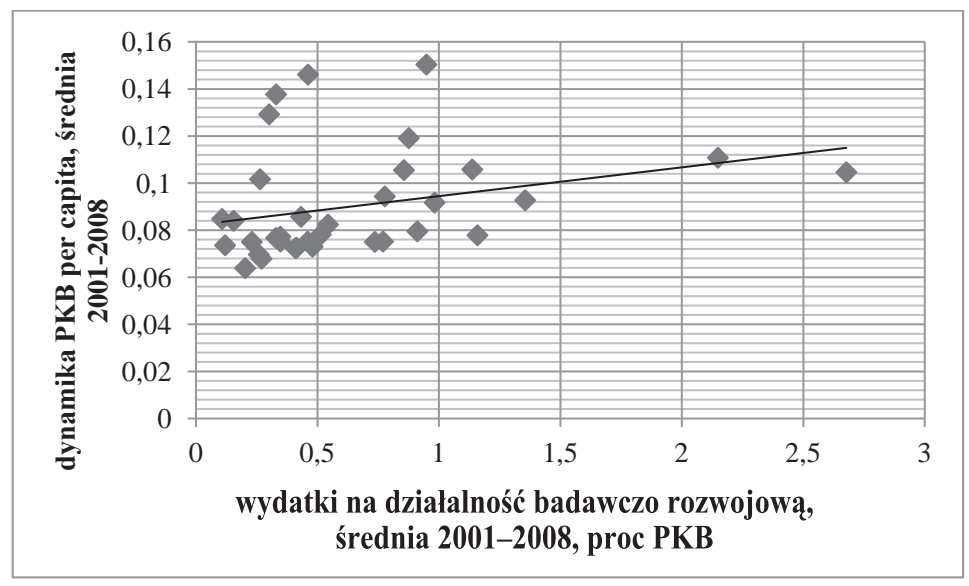

Wyk. 3. Poziom wydatków na działalność $\mathrm{B}+\mathrm{R}$ i dynamika PKB per capita w regionach NUTS 2, 2001-2008

Źródło: opracowanie własne na podstawie danych Eurostat

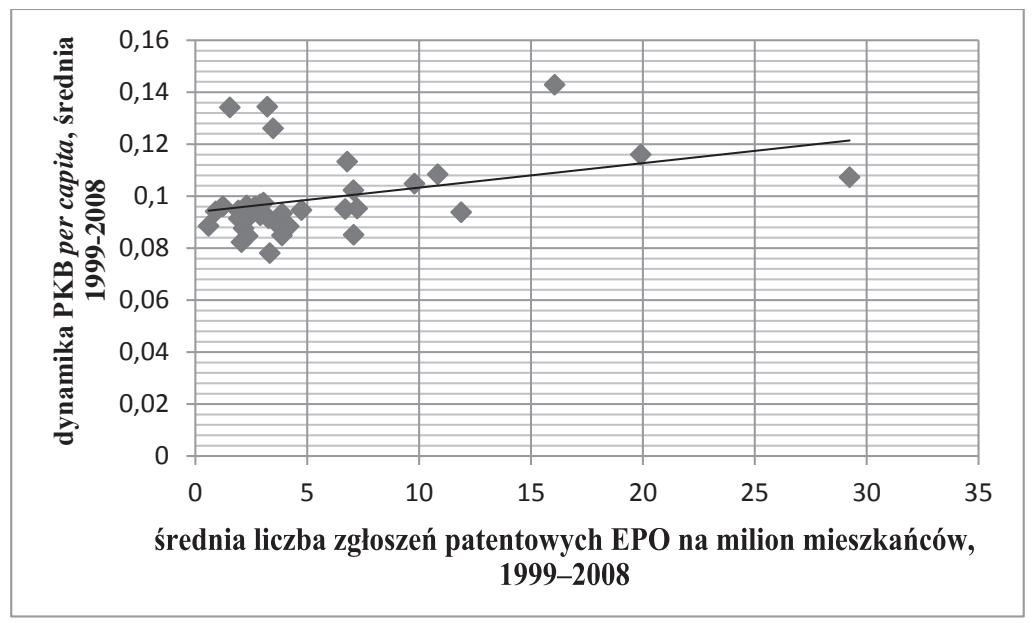

Wyk. 4. Liczba zgłoszeń patentowych i dynamika PKB per capita w regionach NUTS 2, 1999-2008

Źródło: opracowanie własne na podstawie danych Eurostat 
Aby dany region mógł się dynamicznie rozwijać niezbędne jest posiadanie tzw. „masy krytycznej", czyli potencjału intelektualnego niezbędnego do prowadzenia badań zakrojonych na szeroką skalę. Eurostat stosuje mierniki typu HRST (Human Resources In Science \& Technology), które obejmują liczbę osób posiadających wykształcenie wyższe i osób zatrudnionych w sektorze B+R. Pozytywnym zjawiskiem obserwowanym we wszystkich regionach Grupy Wyszehradzkiej jest wzrost udziału pracowników z wykształceniem na poziomie ISCED 5-6 w ogóle zatrudnionych w latach 2001-2007. Grupę regionów o największej dynamice wzrostu tworzą polskie regiony z województwem zachodniopomorskim, śląskim i mazowieckim na czele. W analizowanym okresie, we wszystkich regionach poza stołecznymi, średni udział pracowników z wyższym wykształceniem w ogóle zatrudnionych nie przekraczał 19\%. Najniższy wskaźnik charakteryzował większość regionów Czech i Słowacji. Najwyższy, ponad 27\% udział, zanotowano w regionie Pragi i Közép-Magyarország, a najniższy w regionie północno-zachodnim Czech (Severozápad). Najmniejsze zróżnicowanie regionalne $\mathrm{w}$ tym aspekcie zaobserwowano w Polsce. Korzystnym zjawiskiem sprzyjającym konwergencji jest średnia (a nie jakby się mogło wydawać najmniejsza) wartość tego wskaźnika w trzech spośród pięciu najbardziej problemowych regionów Polski Wschodniej, tj. województwa podlaskiego, lubelskiego i świętokrzyskiego.

Kolejnym czynnikiem kształtującym innowacyjność na poziomie zarówno krajowym jak i regionalnym jest personel zatrudniony w sektorze $\mathrm{B}+\mathrm{R}$. Trudno wyobrazić sobie kreowanie innowacji czy wdrażanie patentów z pominięciem czynnika ludzkiego. Udział sektorów $\mathrm{B}+\mathrm{R}$ w zatrudnieniu ogółem w ujęciu regionalnym prezentuje mapa 3. Na łączne zatrudnienie w sektorach $\mathrm{B}+\mathrm{R}$ składa się zatrudnienie w sektorze przedsiębiorstw, rządowym, szkolnictwa wyższego oraz pozostałych (prywatny sektor non-profit). Według teorii potrójnej helisy (Triple Helix Theory) autorstwa Etzkowitz'a (1998), działalność innowacyjna to produkt współpracy pomiędzy trzema typami instytucji - jednostkami sektora nauki, organów administracji rządowej i przedsiębiorstw sektora prywatnego. Teoria ta wskazuje, że formalne i nieformalne porozumienia pomiędzy sektorem prywatnym i publicznym determinują kształt i poziom wzrostu gospodarczego na danym obszarze. Szczególną rolę odgrywają powiązania między organami administracji lokalnej i regionalnej oraz sektorem nauki. Sektor ten może być reprezentowany przez prywatne uczelnie wyższe, państwowe uniwersytety, a także przez różnego typu instytuty badawczo-rozwojowe i środowisko przemysłowo-biznesowe. Zdecydowanym liderem w zakresie zatrudnienia w sferze badawczo-rozwojowej są regiony stołeczne Czech i Słowacji, odpowiednio 4,15\% i 3,32\%. Kolejne miejsca zajmują regiony stołeczne Węgier i Polski, Jihovýchod i województwo małopolskie. Najbardziej liczną grupę tworzą regiony, w których udział sektorów $\mathrm{B}+\mathrm{R}$ w zatrudnieniu ogółem jest niższy niż 0,74\%. Największym spośród wszystkich analizowanych krajów udziałem personelu $B+R$ w sektorze przedsiębiorstw charakteryzowały się regiony Czech.

Wyniki analizy wskazują na wyraźną dominację sektora szkolnictwa wyższego. Aż w 32 spośród 35 regionów udział szkolnictwa wyższego przekraczał udział sektora rządowego (poza regionami stołecznymi Czech i Polski oraz środkowych Czech: Strední Cechy), a w 25 regionach był wyższy od łącznego udziału sektora rządowego i przedsiębiorstw. Analiza zależności wydatków i zatrudnienia w sektorze $\mathrm{B}+\mathrm{R}$ potwierdziła silny poziom korelacji pomiędzy tymi cechami w regionach Polski, Słowacji i Węgier $(0,93-0,97)$ i dużo niższy w Czechach $(0,56)$. Oznacza to, że w analizowanym okresie wzrostowi gospodarczemu i wydatków na działalność B+R towarzyszył wzrost zatrudnienia personelu B+R. Udział 
personelu badawczo-rozwojowego w zatrudnieniu ogółem był również silnie skorelowany z liczbą zgłoszeń patentowych (współczynnik korelacji Pearsona 0,78), co może świadczyć o tym, że badania prowadzone przez ten personel znajdują zastosowanie w praktyce. Pomimo wzrostu liczby patentów, kraje Grupy Wyszehradzkiej należą jednak nadal do krajów o najwyższym udziale badań podstawowych w strukturze nakładów bieżących na działalność $\mathrm{B}+\mathrm{R}$, co jest cechą charakterystyczną krajów słabiej rozwiniętych, w których działalność $\mathrm{B}+\mathrm{R}$ jest finansowana $\mathrm{w}$ znacznej mierze ze środków budżetu państwa.

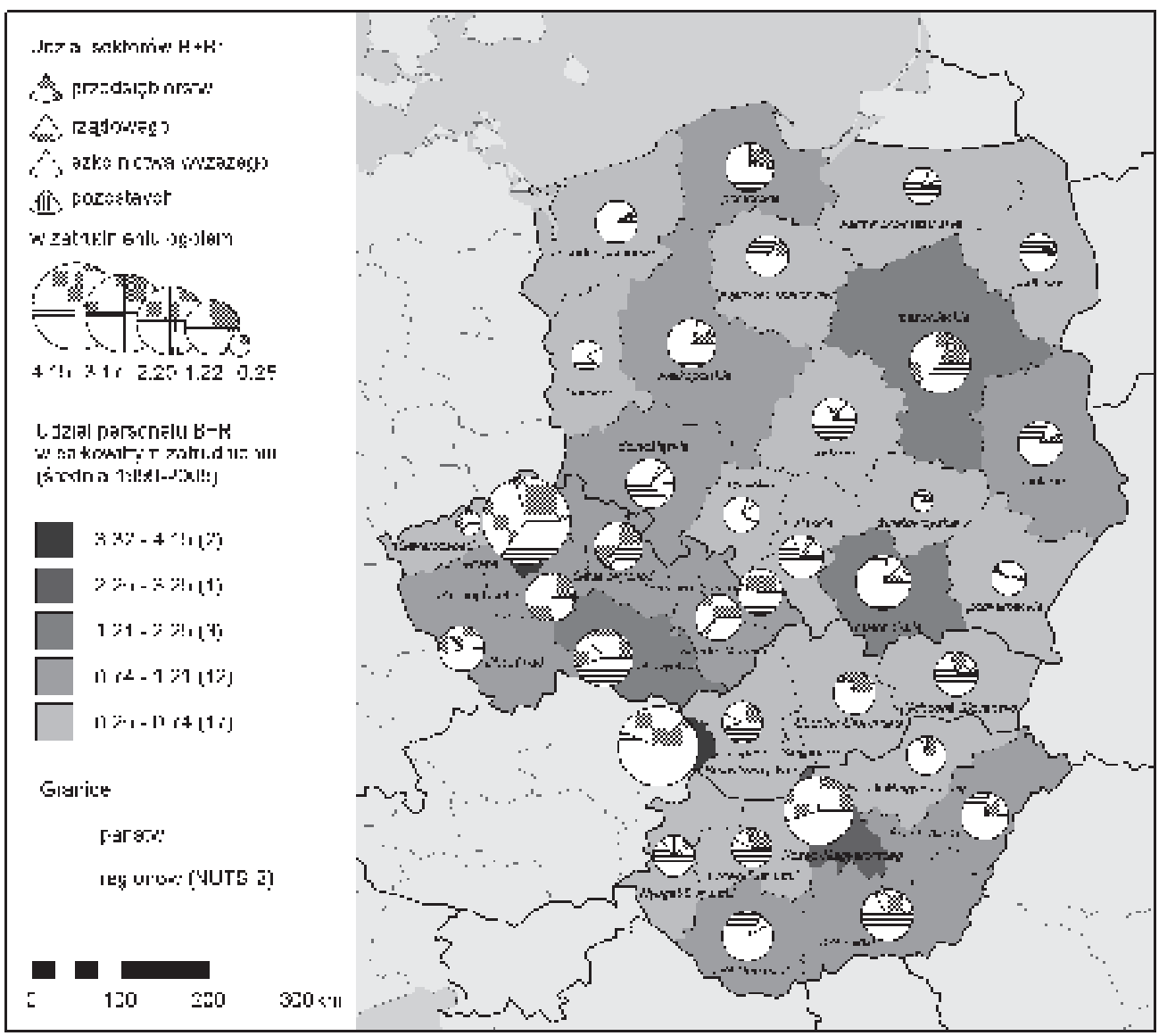

Mapa 3. Zatrudnienie w sferze badawczo-rozwojowej

Źródło: opracowanie własne na podstawie danych Eurostat

W krajach, w których w dużym stopniu wykorzystuje się wysoko wykwalifikowane kadry, poziom innowacyjności i konkurencyjności gospodarki jest również wysoki. W dwóch państwach europejskich: Szwecji i Norwegii, ponad połowa ogółu pracujących zatrudniona jest w sektorze produkcji wysokiej technologii lub sektorze usług opartych na wiedzy, czyli gałęziach gospodarki w największym stopniu wykorzystujących zdobycze współczesnej nauki i techniki. Wyniki analizy zatrudnienia w sektorach wysokich technologii w krajach 
Grupy Wyszehradzkiej wskazują na dużo niższe udziały i znaczne dysproporcje regionalne. Do regionów o najwyższym udziale sektora wysokich technologii w zatrudnieniu ogółem należały (poza regionami stołecznymi) cztery regiony węgierskie: Közép-Dunántúl, Nyugat-Dunántúl, Dél-Dunántúl i Észak-Magyarország oraz jeden czeski: Jihovýchod. Najwyższy wzrost zatrudnienia we wspomnianych sektorach odnotowano w polskich województwach. Do liderów w tym zakresie należało województwo dolnośląskie (region zakwalifikowany do „źródeł wiedzy”) oraz podlaskie. W ostatnim przypadku jednak, podobnie jak w reszcie województw Polski Wschodniej, udział sektora wysokich technologii w zatrudnieniu ogółem należał do najniższych w kraju. Analiza zależności wzrostu gospodarczego i zatrudnienia w sektorach wysokich technologii potwierdziła, podobnie jak w przypadku zgłoszeń patentowych i wydatków na działalność badawczo-rozwojową, średni poziom korelacji pomiędzy tymi cechami w całej grupie analizowanych regionów (współczynnik korelacji Pearsona 0,31$)$.

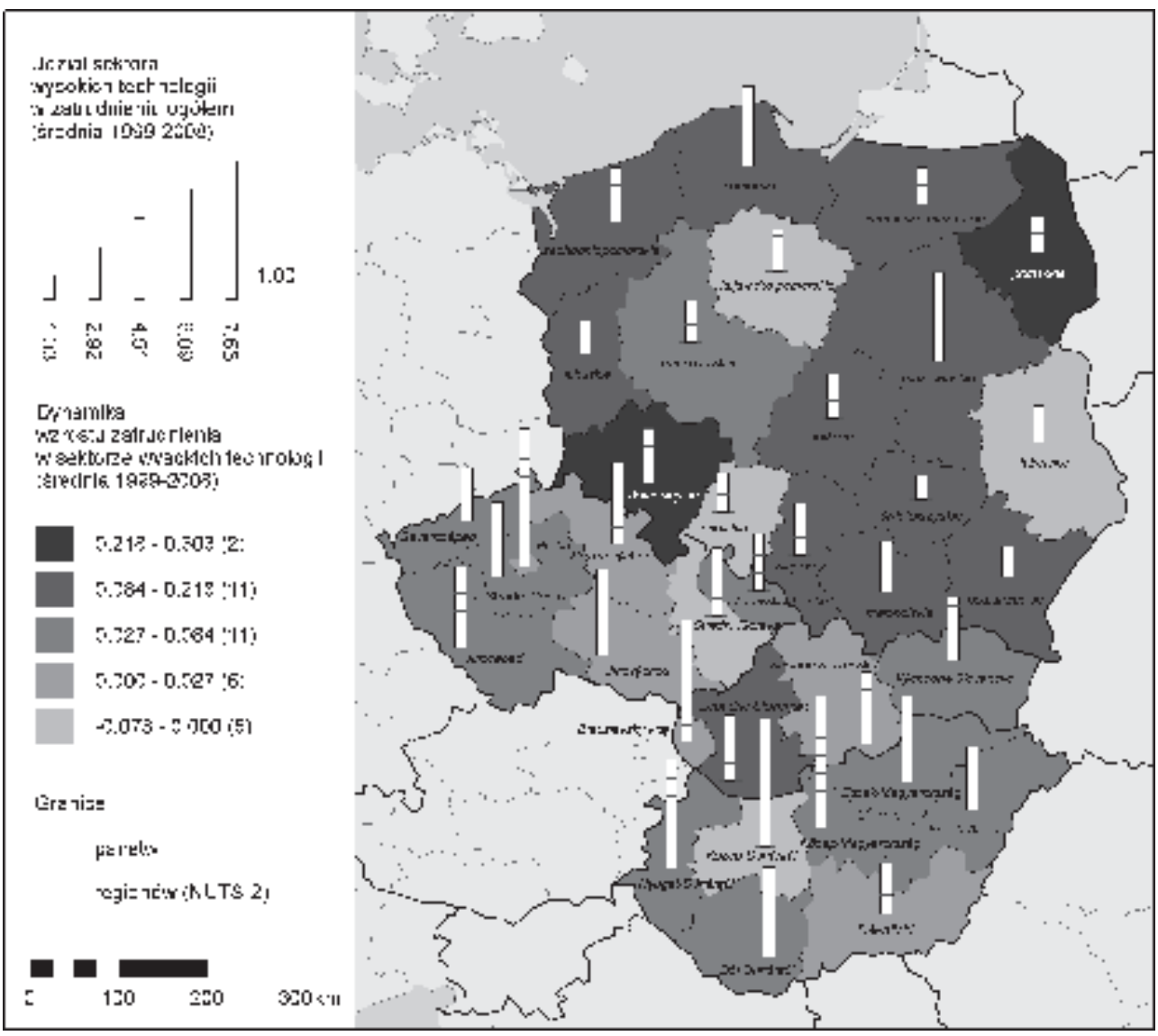

Mapa 4. Zatrudnienie w sektorach wysokich technologii

Źródło: opracowanie własne na podstawie danych Eurostat 


\section{Podsumowanie}

Różnice w rozwoju regionów państw Grupy Wyszehradzkiej wynikają z ich historii, położenia geograficznego, wielkości, czy wreszcie różnych reakcji na proces transformacji. Szybszy wzrost regionów lepiej rozwiniętych prowadzi do wzrostu dysproporcji międzyregionalnych. W przypadku Grupy Wyszehradzkiej za wzrost zróżnicowania odpowiada przede wszystkim szybki rozwój regionów stołecznych i (w mniejszym stopniu) pogłębiające się dysproporcje pomiędzy pozostałymi regionami. Ograniczonym rozwojem lub nawet stagnacją charakteryzują się przede wszystkim regiony słabiej zurbanizowane. Rezultaty analizy potwierdziły istotne różnice w rozwoju regionów w układzie wschód-zachód, ukształtowane w ubiegłych stuleciach i wynikające z sąsiedztwa z krajami bardziej rozwiniętymi (zachodnie Węgry czy południowo-zachodnie Czechy), a obecnie związane z tworzeniem stref rozwoju wokół korytarzy transportowych łączących główne ośrodki Europy Zachodniej i Środkowej, typu: Warszawa-Poznań-Berlin, Praga-Pilzno-Norymberga, czy Budapeszt-Bratysława-Praga-Berlin (Domański i in. 2003).

Działalność innowacyjna w analizowanych regionach wymaga wsparcia, zarówno ze środków publicznych, jak i prywatnych. Wyniki analizy pokazują, że niestety najbardziej liczną grupę regionów stanowią NUTS 2, w których na badania i rozwój przeznacza się średnio mniej niż $0,5 \%$ PKB. Za niepokojący można uznać fakt, że połowę wspomnianej grupy stanowią regiony, w których zanotowano spadek wydatków na działalność badawczo-rozwojową w stosunku do generowanego przez nie PKB. Chociaż liczba patentów w analizowanych regionach stale rośnie, nadal pozostaje ona niższa od średniej UE. Pozytywnym zjawiskiem obserwowanym we wszystkich regionach Grupy Wyszehradzkiej jest wzrost udziału pracowników z wykształceniem na poziomie ISCED 5-6 w ogóle zatrudnionych. Procesowi konwergencji sprzyja średnia (a nie jakby się mogło wydawać najmniejsza) wartość tego wskaźnika w trzech spośród pięciu najbardziej problemowych polskich regionów, tj. województwa podlaskiego, lubelskiego i świętokrzyskiego. Wzrostowi gospodarczemu $\mathrm{W}$ analizowanej grupie regionów towarzyszył wzrost zatrudnienia personelu $\mathrm{B}+\mathrm{R}$. Udział tego personelu $\mathrm{w}$ zatrudnieniu ogółem był również silnie skorelowany z liczbą zgłoszeń patentowych, co może świadczyć o tym, że badania prowadzone przez ten personel znajdują zastosowanie w praktyce. Wyniki analizy zatrudnienia w sektorach wysokich technologii w krajach Grupy Wyszehradzkiej wskazują na znaczne dysproporcje regionalne. Najwyższy wzrost zatrudnienia we wspomnianych sektorach odnotowano w polskich województwach. Wyniki przeprowadzonego badania pozwalają na domniemanie wpływu innowacji na dynamikę PKB per capita i tym samym konkurencyjność regionalną w krajach Grupy Wyszehradzkiej.

Zróżnicowanie regionalne krajów Grupy Wyszehradzkiej i siła wpływu ich miast stołecznych oznaczają, że wnioski dotyczące rozwoju całych państw mogą okazać się daleko idącym uogólnieniem. Za skrajny przypadek można uznać Bratysławę, która sprawia, ze Słowacja należy do grupy najwyżej rozwiniętych państw Europy Środkowej i Wschodniej, podczas gdy większość jej regionów należy do słabo lub przeciętnie rozwiniętych. Narastające dysproporcje między regionem stołecznym a resztą kraju stanowią istotne wyzwanie dla polityki regionalnej wszystkich państw Grupy Wyszehradzkiej. Oznacza to jednocześnie, że odrębnej analizy wymaga również zróżnicowanie regionalne poza regionami stołecznymi. 


\section{Literatura}

Asheim B.T., Smith H.L., Oughton Ch., 2011, Regional Innovation Systems: Theory, Empirics and Policy, Regional Studies, vol. 45, no 7, s. 875-891.

Asheim B.T., Coenen L., 2005, Knowledge bases and regional innovation systems: comparing Nordic clusters, Research Policy, 34, s. 1173-1190.

Bąk M., Kulawczuk P., Szcześniak A., 2004, Bariery rozwoju dziedzin opartych na wiedzy w Europie Centralnej. Strategie pokonywania barier, Instytut Badań nad Demokracją i Przedsiębiorstwem Prywatnym, Warszawa.

Domański B., Guzik R., Micek G., 2003, Zróżnicowanie regionalne krajów Europy Środkowo-Wschodniej i jego zmiany w latach 1995-2000, Biul. Kom. Przestrz. Zagosp. Kraju PAN, nr 204, s. 125-142.

Etzkowitz H., 1998, The norms of entrepreneurial science: cognitive effects of the new university-industry linkages, Research Policy, 27, s. 823-833.

The Global Competitiveness Report 2010-2011, 2010, World Economic Forum, Geneva.

Gorzelak G., 2009, Regional development in Central and Eastern Europe, [w:] P. Blokker, B. Dallago (eds), 2009, Regional diversity and local development in the new member states, Imprint New York: Palgrave Macmillan.

Gorzelak G., Jałowiecki B., 2002, European Boundaries: Unity or Division of the Continent?, Journal of the Regional Studies Association, vol. 36, no 4, s. 409-419.

Grossman G.M., Helpman E., 1994, Endogenous Innovation in the Theory of Growth, Journal of Economic Perspectives, s. 23-44.

Hollanders H., Tarantola S., Loschky A., 2009, Regional Innovation Scoreboard 2009, Innometrix.

Maeninig W., Olschlager M., 2011, Innovative Milieux and Regional Competitiveness: The Role of Associations and Chambers of Commerce and Industry in Germany, Regional Studies, vol. 45, no 4, s. 441-452.

Meyer-Steamer J., 2008, Systemic Competitiveness and Local Economic Development, paper for publication in S. Bodhanya (ed.), Large Scale Systemic Change: Theories, Modelling and Practices, Duisburg.

Rodríguez-Pose A., Crescenzi R., 2008, Research and development, spillovers, innovation systems, and the genesis of regional growth in Europe, Regional Studies, vol. 42, no 1, s. 51-67.

Rozmus A., Cyran K., 2009, Finansowanie działalności badawczo-rozwojowej w Polsce i innych krajach - diagnoza i próba oceny, eFinanse finansowy kwartalnik internetowy, $\mathrm{nr} 4$.

Shearmur R., Bonnet N., 2011, Does local technological innovation lead to local development? A policy perspective, Regional Science Policy \& Practice, vol. 3, no 3.

Schumpeter J., 1911, Theorie der wirtschaftlichen Entwicklung: eine Untersuchung über Unternehmergewinn, Kapital, Kredit, Zins und den Konjunkturzyklus, Duncker \& Humblot, Munich and Leipzig.

Sixth Periodic Report on the Social and Economic Situation of Regions in the EU, 1999, European Commission.

A Study of the Factors of Regional Competitiveness. A draft final report for the European Commission, Directorate-General Regional Policy, Ecorys, Rotterdam, http://ec.europa.eu/regional_policy/ sources/docgener/studies/pdf/3cr/competitiveness.pdf

Vieira E., Neirad I., Vázquez E., 2011, Productivity and Innovation Economy: Comparative Analysis of European NUTS 2, 1995-2004, Regional Studies, vol. 45, no 9, s. 1269-1286. 


\title{
Innovation and regional competitiveness in the Visegrad Group, 1999-2008
}

The paper relates to factors determining regional competitiveness in Poland, Czech Republic, Hungary and Slovakia - the new EU Member States and the Visegrad Group States. In terms of economy, there have been both similarities and wide disparities between these countries. Similarities are due to the socialist economy, which shaped their economic and social systems for several decades. Differences are caused, among others, by cultural factors underlying economic development, administrative and institutional arrangements underpinned by different legal systems, and dissimilar spatial structures. The empirical analysis focuses on innovation as a very important determinant of regional competitiveness because of its substantial impact on productivity. Data basically originate from two different sources: Eurostat Regional Statistics and OECD Regional Database. To avoid generalisations across various types of regions, and using the regional data for the years 1999-2008, I try to indicate regions defined as knowledge hubs. In those regions innovation should have stronger impact on competitiveness than in other regions. The results for the Visegrad Group show an increasing dispersion of regional GDP at NUTS 2, faster development of capital city regions and other big agglomerations, and diversity of regional innovativeness. There is a correlation between innovation indicators (R\&D expenditures and patent applications to EPO) and the growth of regional GDP per capita.

\author{
dr Anna Golejewska \\ Uniwersytet Gdański \\ Wydział Ekonomiczny \\ Katedra Ekonomiki Integracji Europejskiej \\ e-mail: a.golejewska@ug.edu.pl
}

